\title{
A metáfora na ensaística de Borges
}

\author{
Gustavo Ponciano Cunha de Oliveira
}

UFG

\begin{abstract}
Resumo
A metáfora é uma recorrência temática na ensaística de Jorge Luis Borges. Porém, o tratamento dado pelo autor portenho ao objeto ensaiado não foi sempre o mesmo. Do jovem poeta e ensaísta ultraísta ao maduro palestrante, as concepções foram profundamente alteradas. Neste ensaio, pretendemos passar por estas diversificadas concepções para nos concentrarmos em uma delas: a metáfora entendida como possibilidade de convergência de conceitos diversos, mesmo contraditórios. Mais do que tema, defendemos a tese de que esta metáfora é própria ao funcionamento ensaístico de Borges. Para promover o debate, nos apoiamos em textos de Paul Ricoeur, Jaime Alazraki, Joseph Hillis Miller, Joaquina Navarro, Álvaro Salvador, entre outros.

Palavras-chave: Ensaio; Metáfora; Borges.
\end{abstract}

\section{Riassunto}

La metafora è un tema ricorrente nella saggistica di Jorge Luis Borges. Tuttavia, il trattamento che l'autore dispensa all'oggetto testato non è sempre lo stesso. Fra il giovane poeta e saggista ultraísta e il maturo oratore, i concetti sono stati profondamente modificati. In questo saggio, pretendiamo presentare queste diverse concezioni, ma ci concentreremo su una: la metafora compresa come la possibilità di convergenza di concetti dissimili, anche contraddittori. Più di tema, difendiamo la tesi di che questa metafora è di per sé parte del funzionamento della saggistica di Borges. Per promuovere la discussione, azionammo testi di Paul Ricoeur, Jaime Alazraki, Joseph Hillis Miller, Joaquina Navarro, Álvaro Salvador, tra gli altri.

Parole chiavi: Saggio; Metafora; Borges. 
1. BERNÉS, Jean-Pierre. "El periodo rojo de Borges", 1988, p. 25-31.

2. BORGES, Jorge Luis. Obras completas, 2007, p.13-20.

3. As aspas simples diferenciam o personagem 'Borges' do autor Borges. $\mathrm{O}$ mesmo acontece com outros personagens citados que partilham da mesma dupla situação.

4. HILLIS MILLER, Joseph. "O crítico como hospedeiro", 1995, p. 18.

5. HARTMAN, Geoffrey. "Preface", 1979, p. 7.

6. DE MAN, Paul. Blindness and Insight: essays in the rhetoric of contemporary criticism, 1983 , p. 8.
Jean-Pierre Bernés ${ }^{1}$, ao ensaisticamente estudar a recorrência do termo rojo na poesia do jovem Jorge Luis Borges, utiliza uma fórmula marcante nos ensaios do autor portenho que investiga: o pesquisador, ao modo do pesquisado, parte da citação de um fragmento - gatilho para a sua reflexão. Transcreve trecho de uma fantástica conjunção que é um deslocamento com propriedade. Em "El otro", de El libro de arena (1975)2, há um encontro entre o maduro e o jovem 'Borges' ${ }^{3}$. Eles dialogam em um banco que está ao mesmo tempo em Cambridge, Massachusetts, 1969, e em Genebra, 1918. O entrelugar próprio da literatura surge, nessa narrativa, sobreposto em vários de seus elementos constitutivos, tornando-o potencializado. O tempo, o eu, o espaço, distorcidos, formam o êxtase excessivo que permite o impossível encontro que descobre na literatura o campo propício para sua realização. A convergência desloca de tal forma as verdades metafísicas, as certezas ontológicas, que o narrador, o maduro 'Borges', confessa que seu intuito era esquecê-lo para não perder a razão; mas não consegue, permanece perplexo.

Bernés planeja uma possível bibliografia que formaria o livro de versos que o jovem 'Borges', em 1918, afirma ao interlocutor estar escrevendo e cujo título ainda não está definido: Los himnos rojos ou Los ritmos rojos. O pesquisador (e tradutor da obra de Borges ao francês) confessa a influência do texto borgiano em seu projeto quando aproxima crítica e literatura: a inventividade é comum aos dois modos textuais. Como defendem, por exemplo, Joseph Hillis Miller ${ }^{4}$, Geoffrey Hartman $^{5}$ e Paul de Man', esta separação, um dia tida como certa, é agora questionada. A diferença entre crítica e literatura foi abolida; convivem atrelados nos entrelugares da leitura e do texto.

Bernés parte de um discurso, em seus termos, ambivalente e provido de uma singular perversão - a escrita borgiana, que permite o encontro impossível de dois 'Borges'. Deseja aclarar o remoto passado poético do escritor. Bernés amplia a reflexão sobre seu próprio projeto: é, possivelmente, mais que uma leitura que tem um fragmento de ficção contido em si, que tem no texto de Borges seu ponto de partida e seu fim, a fonte de respostas não definitivas às suas dúvidas suscitadas por esse mesmo texto:

Quizás sea también, por una contagiosa fatalidad, una generosa invitación a no limitarse a las apremiantes exigencias de cierta crítica ortodoxa, que no alimenta su legitimidad sino en la convicción con pretensión científica, de teorías discursivas, siempre de vanguardia para emplear el consabido lenguaje de connotación militar, seguras de si mismas, exclusivas, siempre un poco imperiosas, dominadoras y forzosamente fascistas como cualquier discurso, 
y como siempre inexorablemente condenadas a una vejez precoz. ${ }^{7}$

O texto borgiano não concede a Bernés apenas o mero fragmento como gatilho para a reflexão ensaística ou a consciência sobre a coexistência crítica/literatura. A maior herança aqui é um funcionamento interno questionador das verdades e pretensões científicas, dos procedimentos que pretensamente permitem o encerramento do objeto analisado. Bernés, na esteira borgiana, conduz seu ensaio questionando as leituras unívocas, supostamente exclusivas, definitivas e suficientes. Reverbera aqui a constante ocorrência, na ensaística borgiana, de uma convergência insólita, característica que reaparece na produção ficcional de Borges, inegavelmente influenciada pelo ensaio (ao qual se dedicou antes mesmo de assumir-se como contista). Este encontro de, a princípio, inconciliáveis (que Bernés localiza em "El otro") é o motor que desestabiliza a leitura unívoca na construção ensaística borgiana. Estamos em um dos temas diletos do ensaísta Borges, a metáfora; mais especificamente, em uma determinada concepção de metáfora que localizamos em Borges - espaço deslizante que permite encontros entre elementos que, separados por uma hierarquia prescritiva e proscritiva, aparentemente não poderiam se encontrar.

Como ressalta Álvaro Salvador ${ }^{8}$, a opinião de Borges sobre a metáfora não foi sempre a mesma. Para confirmar a divergência, basta comparar a declaração de amor a ela no primeiro parágrafo de “Torres Villarroel”, ensaio de Inquisiciones (1925) - "Quiero puntualizar la vida y la pluma de Torres Villarroel, hermano de nosotros en Quevedo y en el amor de la metáfo-

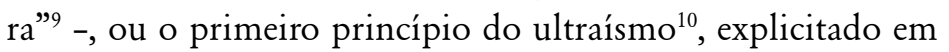
texto programático - "Redución de la lírica a su elemento primordial: la metáfora"11 -, com o que o maduro escritor afirma em "O credo de um poeta", de Esse ofício do verso:

Quando eu era jovem acreditava na expressão. [...] Eu queria expressar tudo. Pensava, por exemplo, que se precisava de um pôr-do-sol devia encontrar a palavra mais exata para pôr-do-sol - ou melhor, a mais surpreendente metáfora. Agora cheguei à conclusão (e essa conclusão talvez soe triste) de que não acredito mais na expressão: acredito apenas na alusão. ${ }^{12}$

As convicções poéticas que guiavam Borges durante sua juventude não lhe convencem mais, ou assim afirma acreditar. Não lhe convence mais o argumento de que a "floración brusca de metáforas [...] representa el esfuerzo del poeta para expresar la milenaria juventud de la vida, que, como él, se devora, surge e renace, en cada segundo" ${ }^{3}$. $\mathrm{Na}$ citação de "O
7. BERNÉS, Jean-Pierre. "El periodo rojo de Borges", 1988, p. 25.

8. SALVADOR, Álvaro. Borges y la fatalidad de las metáforas, 2001, p. 53-64.

9. BORGES, Jorge Luis. Inquisiciones, 1998, p. 9.

10. O ultraísmo é a primeira vanguarda em língua castelhana, surgida entre 1918 e 1925, com duas frentes - a espanhola e a americana - e construída com fragmentos de cubismo, futurismo, creacionismo, expressionismo e dadaísmo. Borges publicou, entre $1920 \mathrm{e}$ 1921, vários textos nos quais defende ideias ultraístas (Cf. VIDELA, Gloria. El ultraísmo, 1971). Mais tarde, o autor refutou o movimento e chamou de "vírus ultraísta" a influência de sua primeira produção poética e ensaística sobre jovens escritores argentinos (Cf. PICKENHAYN, Jorge Oscar. Borges, 1982, p. 30).

11. BORGES, Jorge Luis. Textos recobrados, 2002, p. 128.

12. Idem. Esse oficio do verso, 2000, p. 122.

13. Idem. Textos recobrados: 1919 1929, 2002, p. 31. 
14. Idem. Esse ofício do verso, 2000, p. 112.

15. Idem. El idioma de los argentinos, 1994, p. 51.

16. Ibidem, p. 49.

17. RICOEUR, Paul. A metáfora viva, 2000, p. 79.

18. Ibidem, p. 299.

19. Ibidem, p. 31.

20. Ibidem, p. 30. credo de um poeta" estão associados "metáfora", "expressão" e "palavra mais exata”: Borges refere-se à metáfora enquanto elemento retórico no qual um termo se põe no lugar de outro. E parte para a refutação: "agora vejo que a metáfora é algo muito mais complicado do que eu pensava. Não é meramente a comparação de uma coisa com outra"14. Em "Otra vez la metáfora”, de El idioma de los argentinos, Borges, com seus 29 anos, afirma ter, no início de sua carreira literária, cometido o engano de supervalorizar a metáfora, "consorcio de palabras ilustres"15, ao tratá-la como o feito poético por excelência. "La mas lisonjeada equivocación de nuestra poesía es la de suponer que la invención de ocurrencias y de metáforas es tarea fundamental del poeta y que por ellas debe medirse su valimiento" 16 . Estamos ainda (consideradas essas posições poéticas que o maduro Borges abandona em suas conferências e na refutação dos argumentos ultraístas em El idioma de los argentinos) na recusa da tropologia cara ao jovem ultraísta, da preocupação com a adequação do termo substituto ao termo que substitui. Um termo potencialmente presente que, enquanto ausente, é substituído por outro (e assim passível de ser retomado em uma "tradução" do elemento que o substitui). Estamos ainda rendidos à função decorativa se imaginamos a metáfora como a aplicação de um termo (ideal) no vazio que é a ausência de referência própria a um referente presente, ou seja, preocupação sintática como preenchimento de uma lacuna lexical, como aponta Paul Ricoeur ${ }^{17}$. Borges também demonstrou, ao longo de sua produção, preocupação com a catacrese, em suas palavras, aquele termo cujo caráter metafórico deve ser esquecido para que hoje signifique (reflexões que surgem em textos tão distantes no tempo, quatro décadas, em "Otra vez la metáfora", de El idioma de los argentinos, e em "O credo de um poeta" e "A metáfora”, de Esse ofício do verso).

As concepções de Borges sobre a metáfora são inconstantes, como os juízos ultraísta e contraultraísta. A recusa à tropologia característica do Ultra, promovida a partir de El idioma de los argentinos, já aponta para o entendimento de metáfora que nos interessa: não mais a do nome, mas a da convergência de idéias e conceitos diversos, operação que reúne o distinto, que faz convergir mesmo o contraditório. A epiphorá é o termo aristotélico para "a transposição, a transferência enquanto tal, isto é, o processo unitivo, o tipo de assimilação que se produz entre idéias estranhas, estranhas porque distanciadas"18. Phora, destaca Ricoeur ${ }^{19}$, é uma espécie de mudança segundo o lugar, estabelece Aristóteles no livro III da Física. A epífora é, portanto, definida em termos de movimento, "uma sorte de deslocamento de... para..." ${ }^{20}$. Mesmo em Aristóteles, o interesse sobre a metáfora é no próprio movimento de transposição, no seu processo, mais que em sua possível classe de desvio 
inserida entre outras diversas em uma taxonomia. Isso porque “a epífora é um processo que afeta o núcleo semântico não somente do nome e do verbo, mas de todas as entidades da linguagem portadoras de sentido, e que esse processo designa a mudança de significação enquanto tal" ${ }^{\prime 2}$. O que tentaremos localizar aqui é a compreensão de Borges sobre esta qualidade metafórica, de deslocamento e aproximação de argumentos a princípio contraditórios e inconciliáveis, e o possível emprego dessa metáfora na ensaística borgiana.

Apesar de o maduro Borges de Esse ofício do verso refutar opiniões fundamentais ao jovem Borges, as observações do autor sobre uma metáfora que ultrapassa o tropo surgem ainda nesta produção inicial. Desde seus primeiros ensaios, Borges oscila entre os tratamentos tropológico e discursivo da metáfora. Em diversos textos, aponta como matéria da metáfora não mais a palavra, mas conceitos ou ideias. Em "Examen de metáforas", de Inquisiciones, escreve: "La metáfora es una ligazón entre dos conceptos distintos"22. Em "El culteranismo", de El idioma de los argentinos: "Metaforizar es pensar, es reunir

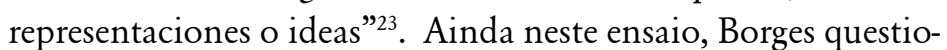
na e redireciona a metáfora de um tratamento exclusivamente estético para o processo cognitivo: “¿Acaso hay un pensar con metáforas y otros sin? La muerte de alguien ¿la sentimos en estilo llano o figurado?”24. A única realidade estética de um poema, defende Borges, é justamente a capacidade operacional (metafórica) de ligar a ideia ou conceito mentalizado com o que se encontra fora deste processo mental. A sensação da morte e o evento morte, por exemplo. Borges desnuda aqui o processo metafórico primordial.

A concepção de metáfora se enriquece com textos do experiente poeta. Em “Ars Magna”, de Atlas (1984), escreve: "Emerson dijo que el lenguaje es poesía fósil; para comprender su dictamen, bástenos recordar que todas las palabras abstractas son, de hecho, metáforas, incluso la palabra metáfora, que en griego es traslación” ${ }^{25}$. Borges compreende, portanto, o caráter espacial da metáfora, de deslocamento ou confluência de idéias em um jogo de palavras abstratas da qual não escapa sequer o funcionamento conceitual da metafísica. Exemplifica-o citando uma metáfora para esse próprio funcionamento espacial, a máquina de pensar de Raimundo Lulio, invento humano que pretende tornar físico a divindade metafísica. Ela é formada por círculos concêntricos de madeira em que estão grafados símbolos dos predicados divinos, heranças de conceitos metafísicos (a bondade, a grandeza, a virtude, a eternidade, o poder, a sabedoria, a vontade e a glória). Os círculos da máquina são girados; seus possíveis resultados são "una suma indefinida y casi infinita de conceptos de orden teológico"26. A máquina de pensar (ela mesma uma metáfora), portanto, torna visível o
21. Ibidem, p. 31.

22. BORGES, Jorge Luis. Otras inquisiciones, 1998 , p. 74.

23. Idem. El idioma de los argentinos, 1994, p. 62.

24. Ibidem, p. 60.

25. Idem. Obras completas, 2007b, p. 528 .

26. Ibidem, p. 528 . 
27. Ibidem, p. 437.

28. O adjetivo transitório, apesar de sua acepção temporal, tem origem em conceito espacial. Do latim, transitorius, "por onde há passagem, que serve de passagem". É derivado do verbo transire, "fazer passar de parte a parte". CRETELLA JUNIOR, José; CINTRA, Geraldo de

Ulhôa, Dicionário Latim-Português, 1956, p. 1270.

29. Idem. Obras completas, 2007a, v. 2 , p. 49.

30. DELEUZE, Gilles; PARNET, Claire. Diálogos, 1998, p. 10.

31. RICOEUR, Paul. $A$ metáfora viva, 2000, p. 14.

32. BORGES, Jorge Luis. Textos recobrados: 1919-1929, 2002, $\mathrm{p}$. 114-115.

33. NAVARRO, Joaquina. "Jorge Luis Borges: Taumaturgo de la metáfora”, 1965, p. 337-344. funcionamento metafórico-espacial de associação de ideias ou conceitos diversos.

A citação de "Ars Magna” é praticamente uma repetição do trecho que abre "'Purgatorio', I, 13”, de Nueve ensayos dantescos (1982): "Como todas las palabras abstractas, la palabra metáfora es una metáfora, ya que vale en griego por traslación. Consta, por lo general, de dos términos. Momentáneamente, uno se convierte en el outro" ${ }^{27}$. Destacamos o caráter transitório $^{28}$ que Borges atribui à conversão metafórica, que surge também em "Quevedo", de Otras inquisiciones (1952): "la metáfora es el contacto momentáneo de dos imágenes, no la metódica asimilación de dos cosas" ${ }^{29}$. Na metáfora, a assimilação entre seus elementos não se dá efetivamente. Um, sem se converter no outro, une-se a ele para que instituam um terceiro elemento, de natureza fendida e instável (o próprio espaço da fusão). A metáfora não exclui a existência dos dois elementos que intrinsecamente a formam, já que isso seria despojar-se de seu próprio estatuto. Como na relação entre heterogêneos no simulacro, não se deixa de ser o que é para devir outra coisa. Aqui está a força da metáfora: "à medida que alguém se torna, o que ele se torna muda tanto quanto ele próprio" ${ }^{30}$, sem que esse movimento implique no fato de um e outro deixarem de sê-los. Ricoeur atribui à metáfora toda a impertinência de um processo que funde opostos: "o 'lugar' da metáfora, seu lugar mais íntimo e mais último, não é nem o nome, nem a frase, nem mesmo o discurso, mas a cópula do verbo ser. O 'é' metafórico significa a um só tempo 'não é' e 'é como"”31. A manutenção dessa diferença no transitório de uma relação impertinente é a operação que interessa à reflexão que aqui realizamos.

Apesar da refutação do maduro Borges, as citações que mais instigam nossa reflexão estão em um texto de seus primórdios, "La metáfora", escrito em 27 de agosto de 1921. É um dos textos programáticos do ultraísmo, mas que não apresenta a virulência iconoclasta e o discurso da empresa inovadora de outros, como "Al margen de la moderna estética", "Proclama" e "Ultraísmo”. A preocupação de Borges neste texto é discutir a efetividade da metáfora, seu uso e o caráter patético, como revela a citação: "Definamos, pues, la metáfora como uma identificación voluntária de dos o más conceptos distintos, con la finalidad de emociones, y estudiemos algunas de sus formas" ${ }^{32}$. A metáfora, nesta concepção, não assimila palavras, nem palavras e coisas. Borges entende a metáfora como confluência (transitória) de conceitos distintos, ideias, discursos, abstrações.

Joaquina Navarro ${ }^{33}$ defende que a concepção borgiana de metáfora do período ultraísta demonstra já uma preocupação com a conjugação, com a possibilidade de fusão. É "la única 
forma a través de la cual el artista va a poder conjurar, como 'demiurgo' o 'taumaturgo', el complejo mundo intelectual-subjetivo sobre el que quiere experimentar" ${ }^{34}$. A pesquisadora defende a relação destas reflexões vanguardistas do jovem escritor com uma metáfora futura, a das ficções de Borges, metáfora como ferramenta de um sistema mental que pensa por meio de associações imprevistas, capazes de refutar a imposição do pensamento lógico. Esta metáfora, já presente nas reflexões do jovem ultraísta, toma força e transforma-se em peça fundamental do projeto poético do ensaísta, contista e ficcionista.

Outro ponto relevante em "La metáfora" é o fato de Borges afastar o hipotético "floreio casual" de uma suposta linguagem puramente figurativa, a literatura. Ele tem a percepção de que a linguagem (entre elas a literária) é inteiramente metafórica:

No existe una esencial desemejanza entre la metáfora y lo que los profesionales de la ciencia nombran la explicación de un fenómeno. Ambas son una vinculación tramada entre dos cosas distintas, a una de las cuales se la trasiega en la otra. Ambas son igualmente verdaderas o falsas. ${ }^{35}$

Não há diferença, defende Borges, entre o cálculo da massa da lua e a metáfora de Nietzsche que a associa a um gato que anda sobre os telhados. São vinculações da lua a outra coisa, mas não rígidas substituições. Borges trabalha na ausência de vínculo entre o ser das coisas e o ser da linguagem. Essas associações enfatizam pequenos detalhes dos elementos acionados para assim adicionar ao mundo novos feitos, novos conhecimentos.

Ainda há, no trecho de "La metáfora" citado, o caráter investigativo e inquietante (que se potencializará no maduro Borges) que leva o jovem poeta a questionar, mesmo que com outros termos, a imposição do logos enquanto estabelecimento da verdade - a diferença (ciência/literatura, discurso cartesiano/discurso metafórico, verdadeiro/falso) surge abolida. Navarro destaca que a reflexão de Borges, ao apontar a capacidade que a metáfora tem de penetrar no mistério do mundo, "en las misteriosas relaciones entre los distintos órdenes de cosas" ${ }^{\text {" }}$, ultrapassa as preocupações plásticas e estéticas ultraístas.

Borges $^{37}$ intenta uma tipologia em seu ensaio. Destaca as imagens que revelam o paralelismo entre dois objetos formais; variações da metáfora sinestésica (transposição de percepções acústicas em visuais e vice versa, como visualização de sons, cor de vogais etc); a metáfora que relaciona conceitos abstrato e concreto, como um objeto ao tempo (cita as Noites: um cabelo de mulher em três tranças cuja visão é a de três noites distintas observadas simultaneamente); e a metáfora que é o inverso da anterior, a que dinamiza o estático, como o espaço
34. Ibidem, p. 338.

35. BORGES, Jorge Luis. Textos recobrados: 1919-1929, 2002, p. 114.

36. NAVARRO, Joaquina. "Jorge Luis Borges: Taumaturgo de la metáfora", 1965, p. 339.

37. BORGES, Jorge Luis. Textos recobrados: 1919-1929, 2002, p. $114-120$. 
38. Ibidem, p. 118.

39. OVERSTREET, David. Oxymoronic Language and Logic in Quantum Mechanics and James Joyce, 1980 , p. 38.

40. Segundo Houaiss (2004b), o verbo relacionar é formado pelo interpositivo fer, originário do verbo latino fero, um termo de natureza fendida: significa, em sua primeira acepção, ao mesmo tempo, trazer ou levar (Cf. CRETELLA JUNIOR, José; CINTRA, Geraldo de Ulhôa. Dicionário Latino-Português, 1956 , p. 468).

41. Ibidem, p. 37. Apesar de Overstreet, nesta citação, defender a sintese em uma unidade (o que contraria a ideia de coabitação não sintética, previamente defendida por nós como constituinte da metáfora borgiana), o trecho nos parece interessante pela defesa do oximoro como superação das dicotomias, que prevalecem no pensamento ocidental.

42. ALAZRAKI, Jaime. "Oxymoronic structure in Borges' essays”. Books Abroad, 1971, p. 421-427.

43. Ibidem, p. 425.

44. Cf. OVERSTREET,

David. SubStance, 1980, p. 37; PREMINGER, Alex; BROGAN, T.V.F. The New Princeton Encyclopedia of poetry and poetics, 1993, p. 873.

45. BORGES, Jorge Luis. Textos recobrados: 1919-1929, 2002, p. 118.

46. Ibidem, p. 118.

47. HILLIS MILLER, Joseph. "O crítico como hospedeiro", 1995.

48. Ibidem, p. 15. que se temporaliza. Porém, o mais instigante elemento desta tipologia, mais um ponto relevante do texto para nossa reflexão, é a metáfora que Borges chama de adjetivação antitética. Seus exemplos revelam que ele trata do oximoro: "universalmente só"; "Looking on darkness which the blind do see", citação do Soneto 27 de Shakespeare ${ }^{38}$.

Segundo Overstreet ${ }^{39}$, a combinação de opostos proporcionada pelo oximoro (pela metáfora antitética, nos termos de Borges) vai além das palavras - alcança o pensamento, uma forma de relacionar ${ }^{40}$. A simplicidade (moron, a idiotice que forma seu nome) é apenas aparente, já que a natureza fendida da relação oximórica fornece uma forma extremamente útil de investigação e questionamento da aletheia, da verdade. "The oxymoron's technical value derives from its ability to overcome dichotomies created by Western (Cartesian) thought. The yoking of opposites in the oxymoronic phrase [...] forces the imagination to synthesize a unique conceptual entity" ${ }^{41}$. Jaime Alazraki ${ }^{42}$ defende que o oximoro é uma tentativa de superar toda a estreiteza que a razão impõe à linguagem ao responsabilizá-la por instituir entidades estáveis, (falácias, na perspectiva de Borges): “it is a 'no' to a reality conceptually ruled by words"

Borges, em "La metáfora", defende que a existência do oximoro é suficiente para provar o caráter provisório e vacilante da linguagem diante da realidade. Sua qualidade antitética torna impossível alcançar o significado exato da expressão que funde opostos. Há algo de indecidível no oximoro, tão fendido como o próprio termo oximoro, que significa "idiotice sarcástica"44. O jovem Borges dá indício de sua consciência deste atributo: "En álgebra, el signo más y el signo menos se excluyen; en literatura, los contrarios se hermanan e imponen a la conciencia una sensación mixta; pero no menos verdadera que las demás" ${ }^{45}$. Polos positivo e negativo não se excluem: contém em si o outro, encerram-se mutuamente numa relação envelopante, como os vocábulos que contém sentidos opostos. "Creo que en árabe aún perduran muchos vocablos que traducen a la vez dos cosas opuestas. Sin ir tan lejos, recordaré el sentido anfibológico de la voz española huésped"46. Remetemos esta reflexão borgiana sobre o termo hóspede, sobre sua qualidade oximórica, à relação parasita/hospedeiro. Hóspede é tanto o que é recebido na casa alheia como aquele que o recebe, hospedeiro. Hillis Miller ${ }^{47}$ faz o percurso etimológico dos termos. O hospedeiro é também o pão consagrado ao visitante, a hóstia de seu hóspede, do inglês medieval oste e do latim hostia - sacrifício ou vítima. A relação é antitética dupla, defende: host é tanto a presença amiga como o estranho invasor, hostil a quem o recebe, possivelmente "o primeiro emissário de uma hoste de inimigos" ${ }^{48}$. 
A consciência de Borges sobre este espaço de conjunção de opostos não se revela apenas no instante em que cita o vocábulo hóspede, mas também ao classificar seu sentido de anfibológico. O qualificativo usado pelo jovem ultraísta deriva do termo latino amphibolus, pelo grego amphíbolos, que significa "equívoco"49, portador de indeterminância de sentido, de equivocidade, duvidoso, ambíguo. A preposição grega amphí é fendida; significa "em volta, de ambos os lados; em torno de; em meio a, entre; a respeito de; em conseqüência de; através de; perto de; cerca de" e equivalente ao termo latino amb(i)-50. Como nos afirma o narrador de "Pierre Menard, autor del Quijote", "la ambigüedad es una riqueza"51, e Borges faz uso constante dela, transformando sua capacidade de deslocamento em ferramenta fundamental de questionamento dos discursos que supostamente estabelecem a "verdade". Este deslocamento, que a princípio concentra-se em termos específicos (hóspede, parasita, anfibológico etc), também está presente em uma unidade mais complexa, a ensaística borgiana.

Ao comparar Borges a outro escritor e ensaísta argentino, Ezequiel Martínez Estrada (1895-1964), Jaime Alazraki afirma: "In both writers we find rejection of philosophical idealism, but in Borges this rejection is also a form of acceptance" ${ }^{52}$. Borges aceita o "idealismo filosófico" (ou metafísica, ou ontologia, ou platonismo - a depender do instrumental utilizado na abordagem) porque o coloca em cena como forma de resistência a ele mesmo no que o pesquisador chama de estrutura ensaística oximórica. Explorar ou questionar a verdade deslocando-a é não ignorá-la, como sugere Derek Attridge ${ }^{53}$. Por isso não é simplesmente falso dizer que Borges é platonista (ou idealista), mas também não é verdade. É que para reverter o platonismo é preciso utilizar seu aparato discursivo. "Os valores não são subvertidos por algo que está fora deles" ${ }^{\text {. }}$. Como defende Ala$z$ raki $^{55}$, todo o discurso da verdade, filosófico e teológico, é rejeitado por Borges enquanto responsáveis por estabelecer a verdade do mundo. Ou, nos termos de Ana Maria Barrenechea ${ }^{56}$, o discurso que fornece ao homem a certeza da concretude do estabelecimento de sua existência é profundamente abalado pelo autor portenho. Borges é um dos metafísicos de Tlön. Assim como as entidades ficcionais de seu conto, compreende que "un sistema no es otra cosa que la subordinación de todos los aspectos del universo a uno cualquiera de ellos" 57 . A metafísica e seus conceitos fundamentais - ser, cosmos, personalidade, tempo etc - são como a rosa amarela que 'Giambattista Marino' vê no instante de sua morte: seus volumes dourados em um canto do quarto "no eran (como su vanidad soñó) un espejo del mundo, sino una cosa más agregada al mundo" 58 .

Enquanto técnica aplicada, o funcionamento metafórico em Borges consiste em não apenas tematizar as ideias metafísi-
49. CRETELLA JUNIOR, José; CINTRA, Geraldo de Ulhôa.

Dicionário Latino-Português ,1956, p. 79.

50. HOUAISS, Antônio.

Dicionário Houaiss da Língua

Portuguesa, 2004.

51. BORGES, Jorge Luis. Obras completas, 2008, p. 536.

52. ALAZRAKI, Jaime.

"Oxymoronic structure in

Borges' essays”. Books Abroad, 1971, p. 422.

53. ATTRIDGE, Derek.

"Introduction: Derrida and the questioning of literature", 1992, p. 12.

54. HILLIS MILLER, Joseph.

"O crítico como hospedeiro", 1995, p. 24.

55. ALAZRAKI, Jaime.

"Oxymoronic structure in

Borges' essays". Books Abroad, 1971, p. 422.

56. BARRENECHEA, Ana

María. Borges: the labyrinth maker, 1965, p. 144.

57. BORGES, Jorge Luis. Obras completas, 2008, v. 1, p. 520.

58. Idem. Obras completas, 2007a, v. 2 , p. 208 . 
59. Ibidem, p. 107-109.

60. Ibidem, p. 107.

61. Ibidem, p. 109.

62. Cf. BERNUCCI, Leopoldo. "Biografia e visões especulares: Borges e Dante", 2001.

63. BORGES, Jorge Luis. Obras completas, 2007 b, v. 3, p. 448.

64. Ibidem, p. 450. cas e suas equivalentes - fazendo-as equivaler, em força importância e alcance, ao mythos literário (como ocorre em diversos de seus contos) - mas fazê-las permear parte de sua reflexão ensaística para aqui também questioná-las, mesmo que o assunto tratado, a princípio, aponte em outra direção. É o que tentaremos exemplificar com uma proposta de relação com a tradição literária que Borges propõe em parte de seus ensaios.

Em "Kafka y sus precursores" ${ }^{\text {, }}$, ensaio de Otras inquisiciones (1952), Borges propõe uma abordagem incomum do vínculo que autores mantém com sua produção anterior: reverte a verdade cronológica linear e a imperativa causalidade na relação precursor/procedente. A idiossincrasia de Kafka, "su voz, o sus hábitos" ${ }^{60}$, é localizada pelo ensaísta em textos diversos - literários, narrativos, poéticos, filosóficos, aforísticos, orientais - que antecedem a produção kafkiana. Um único evento une produtos tão díspares: a escrita de Kafka. A leitura da criação do autor tcheco desvia nossa percepção, ou nos conduz à produção precedente sob uma nova luz que a ilumina. "Su labor modifica nuestra concepción del pasado, como ha de modificar el futuro" ${ }^{61}$. Em última instância, Kafka cria seus precursores, não o inverso.

É esta lógica que, por exemplo, permite a Borges aplicar profundas mudanças nas personagens e eventos da Divina Comédia, além de alterar a própria biografia de Dante Alighieri ${ }^{62}$, para criar o universo do conto "El Aleph". Porém, o funcionamento não se restringe à contística, à qual é recorrentemente associada. A abordagem pouco usual da tradição literária surge, por exemplo (e nos mantendo na relação que Borges trava com Dante), na coletânea Nueve ensaios dantescos (1982). Borges reinventa a Commedia aos nossos olhos ao localizar no Paraíso uma fração de Inferno. No ensaio "La ultima sonrisa de Beatriz" defende a tese, contrariando as tradicionais interpretações, de que o infernal sofrimento de Dante (não o protagonista, mas o inventor) ao perder Beatriz (Viterbo) ressurgirá no Primeiro Motor, no canto XXXI. Imaginando a felicidade, afirma Borges, Dante "nos deja entrever el horror que ocultan esas venturosas ficciones"63. Cita um oximoro de Chesterton, nightmares of delight, e defende: em Dante, ao contrário do poeta inglês, a ênfase está no pesadelo.

'Beatriz' subitamente desaparece. Não está mais ao lado de 'Dante', o conduzindo pelo empíreo. Ele a avista no alto e ela lhe sorri pela última vez. "Ausente para siempre de Beatriz, solo y quizá humillado, imaginó la escena para imaginar que estaba con ella. Desdichadamente para él, felizmente para los siglos que lo leerían, la conciencia de que el encuentro era imaginario deformo la visión" ${ }^{64}$. Os incompatíveis se encontram na leitura metafórica de Borges: a dor e sofrimento, dignas do Inferno, em pleno Paraíso. 
Este procedimento da ensaística borgiana, que contraria os discursos que se pretendem detentores de uma verdade única e inabalável, encontram na voz de autoridade, na erudição uma de suas artimanhas. Borges é dono de uma concisão e de um rigor formal extremamente apropriados a um verdadeiro metafísico: metafísica transgredida em sua própria formalidade, com sua mais fundamental ferramenta, o logos, a palavra, o discurso, postos em crise.

Não é simplesmente falso dizer que Borges é platonista, mas também não é verdade. Há nesta afirmação - que tomamos de Derrida ${ }^{65}$, ao discorrer sobre Mallarmé - a defesa de uma leitura que se situa na confluência de discursos diversos, mesmo divergentes. Ela pode causar estranheza, principalmente à parcela da crítica que defende a exclusiva perspectiva platônica ou idealista dos textos de Borges. Pelo ponto de vista que adotamos neste ensaio, falta a esta parcela da crítica (ou à sua vertente mais extremada) a percepção do polo oposto ao platonismo em Borges e do entrelugar que se forma entre estes antitéticos de seu discurso - não apenas na produção ficcional, mas também ensaística.
65. DERRIDA, Jacques. "La double séance", 1972, p. 235. 


\section{Referências}

ALAZRAKI, Jaime. "Oxymoronic structure in Borges' essays”. Trad. Thomas E. Lyon. Books Abroad. Norman: University of Oklahoma Press, v. 45, n. 3, p. 421-427, 1971.

ATTRIDGE, Derek. "Introduction: Derrida and the questioning of literature”. In: DERRIDA, Jacques. Acts of literature. London: Routledge, 1992, p. 1-29.

BARRENECHEA, Ana María. Borges: the labyrinth maker. Trad. Robert Lima. New York: New York University Press, 1965.

BERNÉS, Jean-Pierre. "El periodo rojo de Borges”. In: POLO GARCÍA, Victorino (Coord.). Oro en la piedra: homenaje a Borges. Murcia, 1987. Murcia: Editora Regional de Murcia, 1988, p. 25-31.

BERNUCCI, Leopoldo. "Biografia e visões especulares: Borges e Dante”. In: SCHWARTZ, Jorge (Org.). Borges no Brasil. São Paulo: Editora UNESP: Imprensa Oficial do Estado, 2001, p. 77-100.

BORGES, Jorge Luis. El idioma de los argentinos. Buenos Aires: Seix Barral, 1994.

. Esse ofício do verso. Trad. José Marcos Macedo. São Paulo: Companhia das letras, 2000. . Inquisiciones. Madrid: Alianza Editorial, 1998. . Obras Completas. Buenos Aires: Emecé, 2007a. v. 2. . Obras Completas. Buenos Aires: Emecé, 2007b. v. 3. . Obras Completas. Buenos Aires: Emecé, 2008. v. 1. . Textos recobrados: 1919-1929. Barcelona: Emecé, 2002.

CORREIA, Heloisa Helena Siqueira. "Metafísica fantástica: a metáfora entre Borges e Nietzsche”. Sínteses. Campinas: Unicamp, v. 12, p. 97-107, 2007.

CRETELLA JUNIOR, José; CINTRA, Geraldo de Ulhôa. Dicionário Latino-Português. São Paulo: Companhia Editorial Nacional, 1956.

DELEUZE, Gilles; PARNET, Claire. Diálogos. Trad. Eloisa Araújo Ribeiro. São Paulo: Escuta, 1998. 
DE MAN, Paul. Blindness and Insight. essays in the rhetoric of contemporary criticism. Minneapolis: University of Minnesota Press, 1983.

DERRIDA, Jacques. "La double séance”. In: $L a$ dissémination. Paris: Seuils, 1972. p. 199-317.

HARTMAN, Geoffrey. "Preface". In: BLOOM, Harold et al. Deconstruction and Criticism.

London: Henley: Routledge and Kegan Paul, 1979, p.7-9.

HILLIS MILLER, Joseph. "O crítico como hospedeiro”. In: . A ética da leitura: Ensaios 1979-1989. Trad. Eliene

Fittipaldi e Kátia Orberg. Rio de Janeiro: Imago, 1995. p. 1149.

HOUAISS, Antônio (Ed.). "anf(i)-“. In: Dicionário Houaiss da Língua Portuguesa. Rio de Janeiro: Objetiva, 2004. Disponível em: <http://houaiss.uol.com.br/busca. jhtm? .verbete $=a n f \% 28 \mathrm{i} \% 29-\&$ cod $=15813>$. Acesso em: 20 maio 2010. . "-fer-“. In: Dicionário Houaiss da Língua Portuguesa. Rio de Janeiro: Objetiva, 2004b. Disponível em:<http:// houaiss.uol.com.br/busca.jhtm?verbete $=$-fer- $\& \operatorname{cod}=88927 \&$ fon $=1 \&$ codigos $=88579 \% 2 \mathrm{C} 88925 \% 2 \mathrm{C} 88926 \% 2 \mathrm{C} 88927>$. Acesso em: 20 maio 2010

NAVARRO, Joaquina. "Jorge Luis Borges: Taumaturgo de la metáfora”. Revista Hispánica Moderna. Philadelphia: University of Pennsylvania Press, n. 1/4, p. 337-344, jan./out. 1965.

OVERSTREET, David. "Oxymoronic Language and Logic in Quantum Mechanics and James Joyce”. SubStance. Madison: University of Wisconsin Press, n. 3, v. 9, p. 37-59, 1980.

PICKENHAYN, Jorge Oscar. Borges: algebra y fuego. Buenos Aires: Belgrado, 1982.

PREMINGER, Alex; BROGAN, T.V.F. The New Princeton Encyclopedia of poetry and poetics. Princeton: Princeton University Press, 1993.

RICOEUR, Paul. A metáfora viva. Trad. Dion Davi Macedo. São Paulo: Loyola, 2000.

SALVADOR, Álvaro. "Borges y la fatalidad de las metáforas". Revista de crítica literaria latinoamericana. Lima: Hanover: CELACP, n. 53, p. 53-64, 2001.

VIDELA, Gloria. El ultraísmo. Madrid: Gredos, 1971. 
